http://dx.doi.org/10.5007/2175-7968.2013v1n31p81

\title{
POR UMA POÉTICA DA TRADUÇÃO
}

\author{
Janaina Rocha de Paula \\ Universidade Federal de Minas Gerais \\ janainardepaula@oi.com.br
}

\begin{abstract}
Resumo: Partindo do ensaio "A tarefa do tradutor", de Walter Benjamin, e sua articulação com o livro Torre de Babel, de Jacques Derrida, buscamos abordar as traduções realizadas por Maria Gabriela Llansol a partir das noções de renúncia e doação. Renunciando a uma forma de tradução inserida na tradição melancólica/maníaca, a tarefa de tradução em Llansol aproxima-se de uma prática poética tendo no dom do amor o seu elemento de abertura.
\end{abstract}

Palavras-chaves: Tradução. Renúncia. Dom. Amor. Letra.

\section{TOWARD A POETICS OF TRANSLATION}

\begin{abstract}
From the essay "Die Aufgabe des Übersetzers" by Walter Benjamin, and its connection with the book Des tours de Babel by Jacques Derrida, we seek to address translations done by Maria Gabriela Llansol from the concepts of resignation and free giving. Surrending to a translation method within the melancholic/maniac tradition, Llansol's translation task approaches a poetic practice, having love as its opening element.
\end{abstract}

Keywords: Translation. Resignation. Gift. Love. Letter.

\section{A tarefa do tradutor}

Tomemos, de início, o ensaio de Walter Benjamin, "A tarefa do tradutor". Apresentado pela primeira vez como prefácio a uma tradução dos Tableaux parisiens de Baudelaire, ele traz uma curiosa 
ambiguidade no título: uma tarefa que é desde já renúncia ${ }^{1}$ " Die Aufgabe", segundo Haroldo de Campos, apresenta uma nuança semântica que transita entre o dom, o dado e a renúncia ou abandono do tradutor. A primeira renúncia ligada à tarefa de traduzir refere-se às implicações entre traduzido e comunicado. Traduzir uma obra literária não quer dizer torná-la comunicável. Como se a tradução estabelecesse uma espécie de pacto de linguagem extraindo as confusões ou desacertos do texto a traduzir.

Eis a primeira renúncia: traduzir não é comunicar, não é tornar acessível, nem ao menos passar uma informação. Isso é o dispensável numa tradução. O que uma tradução deveria deixar passar é o inapreensível, o misterioso, o poético, quer dizer, aquilo que é essencial à obra. Para Benjamin, "nenhum poema se destina ao leitor, nenhum quadro ao observador, nenhuma sinfonia aos ouvintes". De fato, a arte pressupõe a existência corpórea do homem, mas de modo algum a sua atenção. Por isso, uma tradução não está destinada apenas aos leitores que não entendem o original, se assim fosse, também o original só existiria em função do leitor.

A tradução é uma forma e para apreendê-la é preciso regressar ao original, pois é nele que reside a lei da tradução, a lei dessa forma. A possibilidade de traduzir, a "traduzibilidade", parece ser intrínseca a determinadas obras, como se delas partissem a exigência de tradução. Essa injunção da obra por uma forma - forma própria de tradução - pode encontrar, ou não, um tradutor. A exigência e/ou a permissão para a tradução permanece ainda que nenhum tradutor se entregue à tarefa de traduzi-la. E mais, a injunção se mantém mesmo que um tradutor aceite essa missão, trabalhando no fio tênue de uma tarefa que indica desde o início uma renúncia. Isso pelo fato de que a tradução atrai o "original para o seu interior, para aquele lugar único onde o eco é capaz de fazer ouvir, na sua própria língua, a ressonância da obra na língua estrangeira" (BENJAMIN, 1923/2008, p. 91 [trad. João Barrento]).

Assim, para Benjamin, toda tradução é apenas uma forma provisória de lidar com a estranheza das línguas. Na forma operada 
pela e através da tradução o original cresce, evolui em direção a reconciliação das línguas. A finalidade da tradução seria, então, dar expressão à relação mais íntima das línguas umas com as outras em direção à língua pura. Uma língua anterior a Babel, tempo mítico, onde o querer dizer se conjugava com o modo como se diz. Existe uma aproximação entre as línguas no seu querer dizer algo, mas quando tocamos o modo (a forma) como cada uma diz aquilo que quer, o horizonte torna-se a própria Babel. A língua pura daria acesso a alguma coisa que nenhuma língua poderia alcançar isoladamente.

Tentamos tocar o altíssimo das línguas, a língua pura, e deixamos ecoar, pelo nome de Babel, a confusão das línguas e a impossibilidade de uma total reconciliação. O essencial do original, o inapreensível, continua a ressoar nos limites de toda tradução. Existe, então, um núcleo essencial presente no original que guarda a lei da tradução, a sua exigência e, também, aquilo que numa tradução não pode ser novamente traduzido:.

Se quisermos definir com mais rigor esse cerne essencial poderemos dizer que ele é aquilo que na tradução é, por sua vez, o intraduzível. Poderemos extrair dela tanta substância informacional quanto quisermos e traduzi-la, mas permanecerá sempre um resto intocável, no sentido do qual se orientou o trabalho do verdadeiro tradutor (BENJAMIN,1923/2008, p. 89 [trad. João Barrento]).

Revelar o intraduzível, deixar pulsar o estrangeiro no texto traduzido, seria essa a tarefa a que se destina a tradução? A traduzibilidade de uma obra, assim como o seu limite de tradução, aparece nessa imagem do núcleo essencial que resiste à tarefa do tradutor. $\mathrm{O}$ fato de resistir não indica que ela - a obra - deixe de exigir a tradução. Ao contrário, na tarefa de traduzir há um aspecto do original que parece não cindir. A obra é transposta para uma outra 
língua, através de uma forma que visaria à língua pura e, ao operar a tradução, o cerne essencial é transferido integralmente - o inapreensível da obra -, na sua literalidade, permanecendo agora no interior da língua traduzida como o desconhecido que resiste pulsando. A tradução é sempre um "a-fazer", um "a-traduzir", uma exigência pela forma e uma espera pela nova tradução. Ela busca outra coisa que não a reconstituição do sentido e o que se manifesta, através da forma de tradução, é justamente aquilo que dorme no original funcionando, também para ele, como o estrangeiro, como a outra língua. Como operação simbólica, "a tradução toca o original ao de leve, e apenas naquele ponto infinitamente pequeno de sentido, para seguir na sua órbita própria” (BENJAMIN, 1923/2008, p. 96 [tradução de João Barrento]).

$\mathrm{O}$ fato da traduzibilidade ser inerente a determinadas obras não significa que a tradução seja essencial a elas. Entretanto, é a partir dessa exigência de tradução inerente ao original, que se estabelece uma conexão vital entre esse e a tradução. Para Benjamin, a tradução nasce do original, mas não se define apenas como mero meio de transmitir conteúdos, se assim fosse seria preciso pensar que a única aspiração dessa tarefa seria a de encontrar a semelhança com o original, restituindo um sentido perdido. Ao contrário, o original transforma-se ao longo da sua sobrevivência, ele sobrevive, quer dizer, continua a viver nas traduções não porque elas o imitam, mas porque na forma da tradução o original vive na fidelidade ao silêncio que ela preserva. Ao almejar a língua pura, a tarefa do tradutor deve renunciar não somente a comunicação, mas à reconstituição do sentido. O original demanda uma forma $\mathrm{e}$ não o sentido, ele dispensa o tradutor que opera apenas pela via do sentido, na medida em que a lei da traduzibilidade aponta para a forma como uma delimitação necessária à emergência daquilo que é inapreensível.

$\mathrm{Na}$ forma o original continua a viver, alargando os seus domínios. A busca por uma sintaxe compartilhada fixaria a língua original impedindo-a de se renovar constantemente através da lín- 
gua para a qual foi traduzida, esconderia o seu cerne essencial e intraduzível, lugar onde palavra, imagem e sonoridade se confundem. Na forma da tradução "o sentido se precipita de abismo em abismo", até ameaçar no sem fundo. O tradutor que a obra exige, ao se engajar na tarefa de traduzir, renuncia ao sentido em benefício da forma, em benefício de uma literalidade, que revela que "o sentido deixou de ser a linha de separação entre a torrente da língua e a torrente da revelação" (BENJAMIN, 1923/2008, p. 98 [trad. João Barrento]).

Ao tocar o infinitamente leve de sentido, a tradução "fulgoriza o que não era fulgorizado", deixando irromper como clarão os "insignificantes" do texto original (BARRENTO, 2006, p. 144-179). Através da forma, é revelada uma alteridade presente na matéria do original. Como traduzir um texto escrito em várias línguas ao mesmo tempo? Como traduzir o intraduzível? A busca pela forma renuncia ao sentido e à fixação da língua numa sintaxe pré-definida, deixando irromper o intraduzível puro. Ao consentir com essa renúncia, a tarefa de tradução não visaria, justamente, esse núcleo que guarda a lei da tradução e revela o seu impossível?

No livro Torre de Babel, Derrida nos oferece uma valiosa tradução do ensaio de Benjamin. Como numa espécie de colocação em cena do ato de traduzir ${ }^{2}$, ele nos apresenta a tarefa/renúncia a qual o tradutor deve responder. Ao manipular a língua benjaminiana - e aqui é preciso pensar que não se trata apenas do alemão como língua original do autor, mas de todas as línguas presentes num único texto escrito em alemão - o autor trabalha o texto sem tentar eliminar o insolúvel. Entrega-se à tarefa de traduzir como uma espécie de transformação de uma língua para outra, de um texto para outro. E, se na visada da tradução, o alvo é a língua pura, a reconciliação das línguas, ela nos mostra o seu ponto limite. O intraduzível apresenta-se, nessa leitura, sob a forma do nome: Babel. "Pois Babel é intraduzível". Esse nome toca o ponto infinitamente pequeno de sentido, o limite da tradução, deixando viver nele o fulgor do original. 
A tradução visaria esse intangível. É ele que orienta e fascina o trabalho do tradutor e que o faz prometer a reconciliação das línguas. "Ele quer tocar o intocável, o que resta do texto quando dele se extraiu o sentido comunicável, quando se transmitiu o que se pode transmitir, até mesmo ensinar" (DERRIDA, 2002, p. 52). Ainda que essa reconciliação fique sempre em estado de promessa, pois trata-se de uma visada impossível, a tradução, pelo simples apelo a ela, é um acontecimento raro e considerável. Ao renunciar à tarefa de copiar ou restituir um original, ou de encontrar na língua da tradução os significantes que poderiam dizer todo o original, estabelecendo uma correspondência total entre as línguas, o tradutor deixa que este continue a viver no texto traduzido como o que resta de intocável, de insolúvel.

Derrida recupera a figura do caroço e da casca, presente no ensaio de Benjamin, para tecer o seguinte argumento:

\begin{abstract}
A primeira figura que se apresenta aqui é a do fruto e do invólucro, do caroço e da casca. Ela descreve em última instância a distinção que Benjamin não quererá jamais renunciar (...). Reconhece-se um caroço, o original enquanto tal, pelo fato de poder ele deixar-se de novo traduzir e retraduzir. (...) Só um caroço, porque ele resiste à tradução que ele imanta, pode oferecer-se a uma nova operação tradutora sem se deixar esgotar (DERRIDA, 2002, p. 52-53).
\end{abstract}

O fato de ser uma operação simbólica, quer dizer, uma operação de tessitura com as palavras, não implica que ao final de uma tradução, uma completude simbólica seja atingida. Resta o caroço, aquilo que não cinde na operação, resta a coisa da palavra, o seu osso que permanece, sempre, incognoscível. A exigência de tradução nada sofre por não ser totalmente traduzida, visto que é preciso renunciar ao tudo traduzir, como uma louca tentativa de esgotar o sentido e esgarçar a sintaxe. Renunciar a isso é consentir com 
o desconhecido que continua a viver após todas as tentativas de tradução. "Há lugares que nunca chegaremos", nos diz Llansol no prefácio à tradução dos Últimos poemas de amor de Paul Éluard. E ela continua:

\begin{abstract}
Mas, se o mundo desaparecer no sentido da total incoerência, o poema que não cinde irá procurar outro corpo, outro mundo. (...) Não atribuam mais, à arte de cerzir sereno da poesia, o epíteto de estranheza, atribuam-lhe, vós, oriundos de um país que descobriu mundos, o epíteto a-nem-semprepossível (LLANSOL, 2002, p. 18).
\end{abstract}

\title{
2. A tradução/doação em Maria Gabriela Llansol
}

Acompanhemos esse movimento de amor, o gesto dessa amante que trabalha na tradução. Acompanhemos a tarefa dessa amante, que se coloca a traduzir os Últimos poemas de amor de Éluard, nos revelando que há lugares em que a tradução nunca chegará. Maria Gabriela Llansol se entrega à tarefa desejando "traduzir os poemas de uma só vez, num só golpe”, dando voz àquilo que qualifica a sua tradução: a nem sempre possível. Nem sempre possível devolver o sentido original, nem sempre possível restituir, nem sempre possível representar. Mas também, nem sempre possível falar de amor pela última vez. Resta uma palavra, um sopro, um silêncio inscrito nos versos que tentam escrevê-lo: o amor, o silêncio, a morte. Amorte 3 . Pois "estar no amor, persistir em estar nele, não pode deixar de ser fulgor deserto" (LLANSOL, 1994, p. 139).

Encontramos nas traduções realizadas por Llansol, assim como nos seus diários de leitura, uma ampliação desses lugares teóricos. Os seus textos e prefácios dialogam com as idéias de Benjamin e Derrida; as suas traduções realizam o curso de uma operação poética, aproximando línguas distantes no ponto de um "fulgor 
inapreensível pelo estético". Pois nelas, para além da beleza, o que interessa é o dom poético, a partilha do improvável, a justeza de uma imagem, o "fim da realidade semântica, da nuvem tranquila" e o início de um texto que nasce do poema. Llansol trabalha como uma artesã, ao deixar escorrer aquilo que resiste à tradução, o seu impossível. Cria um artifício para transpor esses pontos insistentes para outro lugar, um outro texto, expandindo e ampliando os focos de intensidade. Trata-se aqui de um encontro de corpos, de uma operação que ao aproximar-se do texto/poema a traduzir, passa a refletir em poema. Seguindo os deslocamentos da palavra, a sua força de aproximação, o seu dom profético que anuncia sempre um começo, como o sublima Maurice Blanchot em A besta de Lascaux.

Em alguns dos prefácios que acompanham as suas traduções encontramos a aproximação entre os termos traduzir e verter. Traduzir, nesses casos, é verter para o "idioma Llansol" o texto que lhe solicita. Temos, tanto do lado da língua a traduzir, como do lado da língua que traduz, a persistência de uma outra língua, estrangeira, desconhecida, "uma melodia antiga, a percorrer a forma moderna do poema". "A agulha de outra métrica", uma espinha, um resto (LLANSOL, 1998, p. 10). A tradução, essa tradução operada no encontro do amor com a morte - nesse impossível a se escrever que resiste pulsando na forma, no ritmo e na textura de uma última palavra - é doação, dom de amor ofertado ao texto, ao legente ${ }^{4}$, ao poeta da sua linhagem 5 . Para que ele também receba, agora, no viés desse idioma, a luz do seu silêncio iluminado: "não me foi fácil traduzi-lo. Não vertê-lo, mas dá-lo. Traduzir este poeta, ou outros, faz parte do meu trabalho objectivo. Mas, neste, como objectivar a luz do dia, na luz do dia?", escreve Llansol no prefácio à tradução dos poemas de Rimbaud. Dar a ele o amor, a luz do dia, "a pulsão da escuridão localmente iluminada", para que o poema saia como entrou: com o mistério que trazia. Temos inscrito no mesmo gesto a renúncia a uma forma de tradução esclarecedora e a doação de uma língua, um corpo, uma leitura, para que o poema persista no seu desejo de apresentar o real. 
No prefácio à tradução dos poemas de Paul Verlaine, partindo da palavra que dá nome ao livro em Francês - Sagesse - Llansol tece o seguinte comentário:

\begin{abstract}
Sagesse é o título do livro. Obviamente não posso traduzi-la por sabedoria, pois a sabedoria é a razão que levou a mandar cortar as árvores - afastar o desenvolvimento progressivo dos ratos, a humidade crescente, ou o perigo do incêndio. Não a posso traduzir por sabedorias, desarticular a palavra em saberes práticos, no plural que torna obscura a unidade. Abro o sentido do livro, a ondulação fluente dos contrários e, através dele, quase encontro Verlaine, como ele gostaria de ser reconhecido por mim - num alto, olhando a cidade, sentado debaixo de uma árvore. (...) Que fazer senão tornar as imagens cada vez mais simples, Sageza é diferente de sabedoria, e contém mais - contém mais o quê? Tenho a experiência de ser uma tradutora livre, e um autor com livre arbítrio. Mas aqui a liberdade por que optei traduz-se na liberdade de ir no rasto do poema até encontrar o autor sentado próximo ao texto, e falando para mim. É, sem sombra de dúvida, um devaneio que estou a ter, um devaneio de um tradutor que é também autor. Será a palavra Sageza a justa para enunciar o livro? Sagaz na sabedoria é o caminho por onde vai a palavra - e encontra uma clareira onde eu suponho que alcancei estes poemas, com o desejo profundo de obedecer às suas regras (LLANSOL, 1995, p. 8)
\end{abstract}

Transitando no vestígio da palavra, a escolha pela "livre tradução" obedece a uma só regra: o poema. Não se trata aqui de mimetizar a outra língua, mas de seguir o passo, a voz do poema, a materialidade da sua letra ${ }^{6}$, buscando uma passagem para o mais amplo. Essa fidelidade se anuncia, em vários momentos, como uma completa desobediência às normas de uma tradução que visaria uma gramática compartilhada, através da correspondência dos significantes (como se fosse possível encontrá-los!). Quer dizer, a 
tradução pensada apenas como o transporte de sentido, na tentativa de encontrar a palavra exata para dizer aquilo que o poema silencia em outra língua. Encontramos, no gesto dessa tradutora, um movimento que se distancia do descrito acima. $\mathrm{O}$ que suas traduções nos oferecem é a "exposição da relação interior das línguas entre si", o seu "pas-de-sens", desdobrado num passo de sentido, sem o intuito de acomodá-lo num sentido único. Esse gesto é apresentado na tradução do título do poema "Marine", de Paul Éluard, traduzido por: "Marinha Marinheira Maresia". O desdobramento do título, a partir da palavra que o escreve, aproxima-se da voz de um poema que anuncia: "C'est le commencement du monde". "Acorda para que eu possa seguir-te os passos/Tenho um corpo para t'esperar p'ra ir atrás de ti/Das portas da aurora às portas da sombra/Um corpo para passar a vida a fazer-te amor/Um coração para sonhar do lado de fora do teu sono (ÉLUARD, 1963/2002, p. 293)". E, então, o amor, de novo, o novo, esse dom, e o traço de um corpo iluminado pela sombra que o ocultava, riscando no espaço da leitura o gesto de uma tradução/doação. A leitura dos poemas risca, no espaço e no corpo de Maria Gabriela, o traço incandescente, a pujança da vida escrita em percurso de água, a morte, a dor, o abandono, a rua vazia, a erva que tem chuva, o cão perdido, o pão, o silêncio de deus, o amante. É em direção a esses "vivos", a essas letras vivas, corpo de diálogo que estabelece com os poetas da sua linhagem, que se dirige a tradução.

Para Lúcia Castello Branco, trata-se, aqui, de uma "tradução legente" ", em consonância com um projeto de escrita. Essa idéia de um legente a traduzir, coloca as traduções de Llansol como um trabalho que se segue àquele da leitura intensiva; uma leitura que passa obrigatoriamente pelo corpo que lê e por uma forma de escrita do texto nesse corpo. Uma leitura em que o corpo é atravessado e possuído por esses focos de intensidade que se desprendem do texto, ao mesmo tempo que é despossuído de um saber que possa extinguir o que, no texto, é o seu impossível. É nesse atravessamento que a tradução opera, colocando em primeiro plano 
a legente Maria Gabriela, aquela que é tomada por esses focos de intensidade, fazendo do seu corpo um lugar para as primeiras formas de escrita, sem abolir o impossível a escrever. No diário Um falcão no punho, encontramos a expressão dessa leitura que ao se desocupar de um saber sobre o texto, pode realizar-se na despossessão e na fruição dos corpos textuantes: "só me restavam forças para, na imobilidade, ler, acrescentando-lhes o gozo ilícito do meu próprio corpo. Sob o signo da falta, eu gozava e lia e, agitando-me sem violência, nesta contradição fundava a escrita" (LLANSOL, 1985, p. 8).

Figurar o real através de uma língua fulgor, figurar o real, quer dizer, torná-lo figura lançada no espaço das "cenas fulgor". Tomá-lo por figuras que abandonaram a via representativa para passarem à via da demonstração, ou via dos afetos. Esse parece ser o trabalho de tradução que Maria Gabriela Llansol realiza. Seguindo uma linhagem poética e, após traduzir Dickinson, Verlaine, Rilke e Rimbaud encontramos a tradução dos poemas de Thérèse de Lisieux. Para que não fiquemos confusos quanto à entrada de uma poeta ligada à tradição mística nessa linhagem, Llansol nos oferece, no prefácio que acompanha a tradução do $O$ alto vôo da cotovia, a seguinte explicação: “ de facto, Teresa Martin surgiu-me na casca de uma árvore - há muito tempo -, quando eu ainda não trabalhava o texto mas ele, através do que eu lia, já trabalhava por mim" (LLANSOL, 1999, p. 7). À cena de uma leitura e ao trabalho do texto no corpo daquele que lê, é possível enlaçar leitura e tradução como dois movimentos simultâneos, que ditam o tom da operação realizada por Llansol, tanto na tradução dos poemas de Thérèse, quanto na composição dos livros que se seguiram a essa tradução: Ardente texto Joshua e $O$ jogo da liberdade da alma. Neles, Thérèse torna-se figura da obra, trazendo, ao lado do nome agora transposto, elementos retirados dos seus manuscritos autobiográficos. 
Li seus poemas. Reparei que são, quase todos de circunstâncias. (...) Correctos, respeitam as formas da métrica e da rima

Perguntam-me se é escritora.

Respondo-lhes que, em escassos quatro anos, a poesia foi servida como mandam os manuais.

Mas vou responder-lhe de outro modo. A Teresa entrou, de facto, no armazém dos sinais da literatura. Noto que foi buscar imagens e ritmos a Musset, a Chateaubriand e a Lamartine. Que entrou, se serviu como entendeu, e fez poemas. Também foi buscar pensamentos e palavras aos Evangelhos, a São João da Cruz, à mística carmelita. As freiras, suas irmãs, apreciavam. Tudo rimava, apesar de quase nada respirar (LLANSOL, 1999, p. 12).

O que Llansol lê nos poemas e cadernos de Thérèse é algo que está para além do que os manuais lhe ensinaram. Aquilo que ficou guardado nos manuscritos, resistindo ao movimento de acomodação através das inúmeras edições do livro História de uma alma. A autora busca a linha que une Thérèse a outras densidades poéticas, aos sons e ritmos que fazem da poesia uma composição que chama o corpo para a cena de leitura. Busca em Thérèse a "pulsão da escrita" ", a força dos afetos que lançaram a jovem carmelita ao "armazém dos sinais da literatura"; aquilo que no texto evoca uma imagem, uma cena fulgor, uma forma. Talvez por isso Llansol apresente a sua tradução, ora dizendo que "sempre fiel à letra, entrei no teu lance"; ora revelando que "aqui, não fui fiel. Era simplesmente impossível". Essa não fidelidade a uma forma de poesia definida nos manuais parece indicar uma extrema fidelidade à letra do poema que "começa na aurora". A legência produz um encontro inesperado entre a "língua fulgor" de Llansol e o corpus textual de Thérèse e, desse encontro, temos um trabalho que passa pela tradução desses poemas e avança para além, transpondo para os textos criados os intentos da letra. De fato, ao traduzir os poemas Llansol 
não produz modificações que sejam simples adulterações do texto original. Como uma artesã, insistimos, ela opera com extrema delicadeza, deixando que o tecido textual revele os seus intervalos. Assim, nesse texto em que "tudo rimava", algo passa a respirar.

Ainda no prefácio à tradução dos poemas de Thérèse Martin, Llansol escreve:

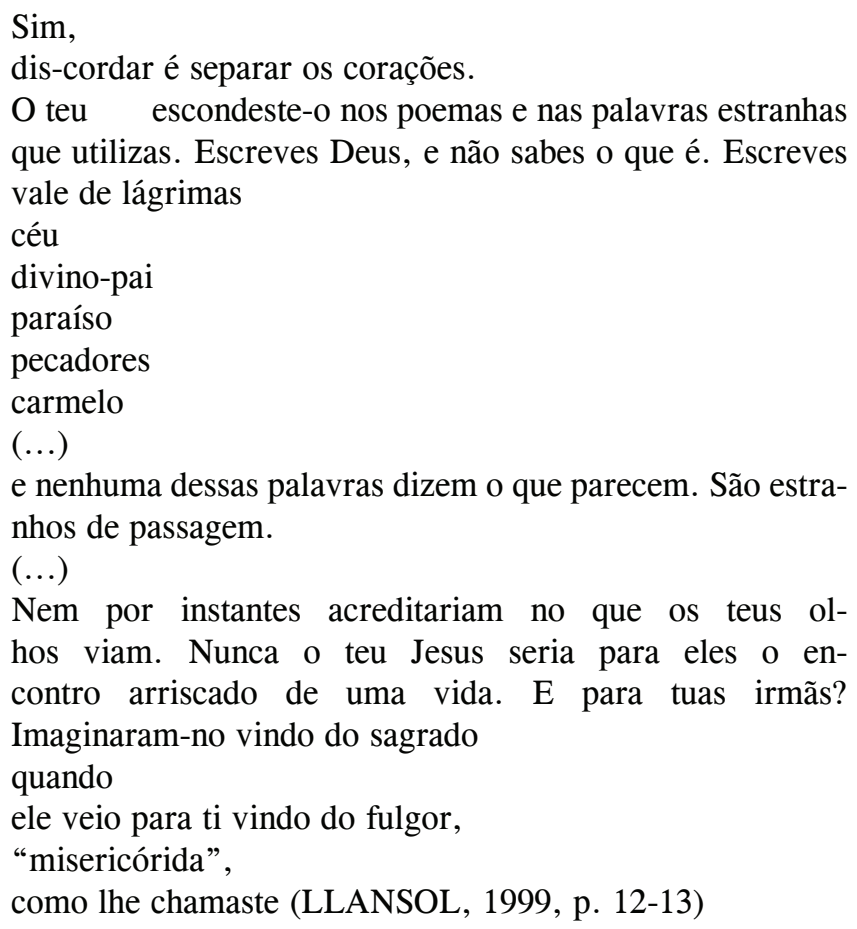

É em direção ao fulgor que essas traduções avançam, "no encontro radical de uma vida", levando o texto a arriscar-se por lugares insólitos, no risco da palavra que por vezes se ausenta, substituída por um traço que escreve a pujança capturada pelos olhos. Talvez pudéssemos dizer que em Llansol a tradução não se desvincula de 
uma experiência de leitura, que toma o texto no seu ponto mínimo de letra, mônada que acumula o intenso presente nesses "corpos de força e afeto" (LLANSOL, 1985, p. 142), desdobrando-o sem dispersá-lo. Para João Rocha, temos, com Llansol, um tradutor que procura "a melhor maneira de fazer com que a poesia habite o poema na tradução". Esse gesto responde à única procura da poesia: olhar sem cindir. Quer dizer, "o tradutor deve, no seu ofício, saber fazer com que o sentido conviva com as palavras". Seguir o seu "curso natural" e isso, só é possível, "se pensarmos que tradução é metamorfose" (ROCHA, 2011, p. 123). Assim, essa tarefa implica uma transformação do original, na medida em que a tradução se apresenta como uma operação literária, análoga à criação poética. Isso porque essa transformação do original permite que ele continue a viver, não no sentido de uma vida póstuma, mas da renovação do vivo da obra (perviver). Mantendo o silêncio do poema nas traduções operadas, encontrando uma forma que possa abrigá-lo nessa língua ofertada, sem cindi-lo, eis a única responsabilidade do poeta/ tradutor: ir mais além. Na fidelidade do silêncio que o poema escreve, na responsabilidade a uma forma de língua sem impostura.

Distanciando-se da tradição melancólica que apontava um horizonte de sombras para a tradução, pela impossibilidade de se alcançar o original - já que tocamos sempre no intraduzível e na impossibilidade - e, no seu oposto, de uma tradição maníaca que entende a tradução como sendo um trabalho "dotado da mesma autoridade do original" (LAGES, 2007, p. 95), o que temos em Llansol é uma doação de corpo para que o corpo de um outro, em poema, possa estender-se sobre o seu, avançando através do "le dur désir de durer" (Éluard, 1963).

\section{A forma que tece em poema}

Retornemos a Babel, o nome, a forma exigida pelo texto original benjaminiano 9 . Ao tratar da tradução, Derrida prefere operar 
uma tradução do texto de Benjamin ao invés de discutir sobre essa tarefa de modo teórico. Esse autor se coloca a traduzir reconhecendo, desde o início, que a tradução guarda relações estreitas com a transposição poética. Traduzir é transpor um nome próprio - "o intraduzível, a letra” - em várias palavras. É transpor através de uma forma "esse tutano intraduzível da língua" (PAZ, 2006, p. 8) que resta como o caroço que não cinde diante da injunção tradutória da obra. "Um resto do texto benjaminiano restará, ele também, intacto ao final da operação. Intacto e virgem apesar do labor da tradução, por mais eficiente e por mais pertinente que ela seja”, nos diz Derrida (2002, p. 52).

Diante desse resto a forma Babel - ela mesma material - parece tocar nesse ponto de contato ou carícia, lugar em que a tentativa de supressão das diferenças das línguas as revela mais plenamente. Babel é a forma na qual sentido e literalidade não se dissociam mais, formando o corpo de um acontecimento único, agora intransferível. O que se passa entre o original e a tradução parece ser aquilo que Derrida nomeia como um "pas de sens", literalmente o sem sentido, mas na forma original encontramos uma ambiguidade da qual o autor parece se beneficiar. Assim, "pas de sens", "não significa pobreza, mas "pas de sens" que seja ele mesmo, sentido" (DERRIDA, 2002, p. 70-71), ou melhor, passo de sentido.

Ao trabalhar na tarefa de tradução, Derrida toca o caroço do texto benjaminiano, transpondo para a forma Babel esse vivo do texto, pois Babel prescreve e interdita a tarefa. Ao recuperar o nome Babel de um outro texto de Benjamin, ele nos mostra, no seu ato, o trabalho de transpor isso que resiste na língua original como o seu núcleo essencial, o seu intraduzível. Operando na dimensão material do signo, conforme à letra do texto, o nome Babel rompe com a unidade orgânica entre conteúdo e linguagem própria do original. Na poética desse nome, o passo/ato do poema: marca singular, assinatura que repete a confusão impronunciável. Assim, "num único algarismo", o nome sela juntamente o sentido e a letra, como um "ritmo espaçando o tempo". 
No ensaio "Música da palavra e tradução", Borges levanta a suspeita de que as traduções literais - que tomamos aqui como conforme a letra do texto, à sua pulsação - tiveram uma origem teológica. Ao traduzir qualquer poeta por maior que fosse - e Borges se refere aqui a Homero - sabendo-o humano, os tradutores podiam remodelar suas palavras. Quando, porém, se passou a traduzir a Bíblia, porque se julgava que esse livro tivesse sido escrito pelo espírito santo, não era mais permitido alterar a letra de Deus.

Se Deus escreve um livro, se Deus se digna à literatura, então cada palavra, cada letra, como dizem os cabalistas, há de ter o seu propósito. E pode ser blasfêmia se intrometer no texto escrito por uma inteligência infinita, eterna (BORGES, 2000, p. 78).

As traduções literais servem à beleza, pois fiel à letra do texto, revelam a estranheza presente na própria obra, mas também a sua singularidade. Uma tradução literal "sempre nos dá aquelas pequenas sacudidelas de surpresa pelas quais esperamos" (BORGES, 2000, p. 79). Justamente por manterem, no texto traduzido, os pontos de intraduzibilidade presentes no original, sem tentar restituir-lhe o sentido perdido.

Assim, a partir dos argumentos apresentados por Derrida, na sua leitura do ensaio de Walter Benjamin, passando pela tradução/ doação em Llansol, somos levados a aproximar a tarefa de tradução de uma prática poética. Uma poieses, diríamos, um trabalho rigoroso, incessante, arriscado e aberto que opera com a "substância lenhosa da língua" ${ }^{10}$, com seu vórtice vibratório, a sua pulsão. É essa aproximação que nos permite dizer, diante de algumas traduções, que não se trata de "poema traduzido de outro, mas um poema tecido ao redor de outro" (BORGES, 2000, p. 80), ou, ainda, poema doado ao outro. Nesse ponto mesmo onde algo resiste e "germina sem poder vir aos lábios". 
É noite sendo dia - a pulsão da escuridão localmente sendo iluminada. Inverto os ritmos. A energia da manhã penetrando o obscuro que sempre me cansa, dando-me a sensação de que estou repleta. Olho, enfim, o poema com que terminei a tradução: "Sonho". (LLANSOL,1998, p. 11)

Eis a forma de tradução que tece em poema, renunciando ao ideal de uma completude narcísica, de um todo simbólico, para desembocar no sonho que se torna escrita ofertada pelo dom do amor, fazendo da língua, tocada pela expansão dos corpos, um horizonte de reconciliação e de diferença. Sendo dia nessa noite, o poema que lhe chega em "Sonho" permite que o olhar se disperse para além das línguas conhecidas, dirigindo-se para um reencontro, sempre novo, com o intraduzível que não cinde e se escreve no poema aberto.

\section{Notas}

1. Apesar dessa ambiguidade não ser partilhada por todos os tradutores do texto de Benjamin, principalmente por aqueles citados na bibliografia deste artigo, persisto com a ideia apresentada por Haroldo de Campos em seu ensaio "O que é mais importante: a escrita ou o escrito?", pelos motivos que se seguem: a renúncia suportada pela palavra "Aufgabe" nos permite articular, na literalidade do passo benjaminiano, uma tradução que se beneficia da forma em detrimento do sentido; o abandono de uma tradução comunicacional em favor do "dom", da "redoação", da ressuscitação, através da tradução, do vivo da obra. Além disso, se seguirmos o texto de Benjamin à risca, leremos que na radicalidade de uma tradução "plena de forma" é a palavra, e não a frase, o elemento originário do tradutor. Num dos prefácios que acompanham as suas traduções Llansol escreve: "Procuro é a palavra". Forma que nos permite ler que a procura é pela Palavra e/ou que Procura é palavra que define as suas traduções. De um lado e de outro, prevalece a palavra como elemento originário do tradutor. Mantemos, portanto, a ambiguidade da palavra. 
2. Derrida trabalha com uma versão do texto de Benjamin traduzida por Maurice Gandillac. "Em lugar de traduzir de modo teórico, tentar traduzir à minha maneira a tradução de um outro texto sobre a tradução". (DERRIDA. 2000, p. 26).

3. Neologismo lacaniano que aproxima amor e morte, apontando para uma forma de amor distante do ideal narcísico de fechamento e completude. O amor, nesse caso, é abertura, e implica, como bem o definiu Maria Gabriela Llansol, com a noção de "amor impar", um terceiro elemento. Ver: LACAN, 1972-1973, p. 53120; LLANSOL, 2004, p. 34.

4. Figura do texto llansoliano, o legente é o que Llansol definia como sendo o "leitor real", quer dizer, aquele que toma o texto não por ficção, nem por verdade, mas por caminho transitável" (LLANSOL, 2001, s/p).

5. Llansol se inscreve numa linhagem de autores que têm "uma mesma vibração", uma "mesma espiral luminosa interior", aproximando-se não por hereditariedade, mas por compartilharem, em espaços distintos de tempos, a mesma problemática. São autores que convergem por buscarem em seus textos a passagem, ou a radicalidade, de uma escrita que volte a significar o real. Dessa linhagem, podemos destacar os poetas que Llansol traduziu: Rilke, Emily Dickinson, Terésè de Lisieux. E também aqueles que se tornaram figura em sua obra: Pessoa, Camões, Holderlin, Nietzsche, entre outros.

6. Trata-se aqui da noção de letra tal como Lacan a formula a partir da leitura de Joyce. Desvinculada da noção de mensagem, a letra vai sendo tomada a partir da sua qualidade tipográfica. Letra como traço, elemento mínimo de uma escrita, resto caído do todo depurado, que se desloca por espaços heterogêneos desenhando um litoral entre saber e gozo. Por não estar atrelada a uma cadeia significante, mas marcar, por sua unidade mínima, uma pulsação, o seu deslocamento produz aquilo que Lacan nomeia como "pas de sens". Ver: LACAN, 1998, p. 13-68; LACAN, 1986, p. 17-23.

7. Essa idéia foi apresentada por Lúcia Castello Branco em sua Tese para Professor Titular de Estudos Literários da Faculdade de Letras da UFMG, em 2009.

8. Expressão de Llansol retomada e trabalhada por Vania Baeta em sua tese de doutorado. In: BAETA, Vania. Luz preferida: a pulsão da escrita em Maria Gabriela Llansol e Thérèse de Lisieux. Tese de doutorado apresentada ao programa 
de pós graduação em letras (estudos literários) da Faculdade de letras da UFMG, 2006.

9. Derrida esclarece que a referência a Babel aparece de maneira explicita em outro texto de Benjamin: Mythe et violence, traduzido por Maurice de Gandillac. Ao dar esse nome ao seu livro, Derrida parece operar uma espécie de transposição disso que resta intraduzível no texto benjaminiano. Babel como o intocável e, ao mesmo tempo, como aquilo que incita à tarefa outros tradutores.

10. Para Agamben "quem nunca alcançou, com num sonho, esta substância lenhosa da língua, (...) ainda que se cale, está prisioneiro das representações" (AGAMBEN, 1999, p. 29).

\section{Referências}

AGAMBEN, Giorgio. Idéia da prosa. Tradução de João Barrento. Lisboa: Edições Cotovia, 1999.

BAETA, Vania. Luz preferida: a pulsão da escrita em Maria Gabriela Llansol e Thérèse de Lisieux. Tese de doutorado apresentada ao programa de pós graduação em Estudos Literários da Faculdade de letras da UFMG, 2006.

BARRENTO, João. Fulgor e ritmo: tradução em Maria Gabriela Llansol e Herberto Helder. In: O arco da palavra. São Paulo: Escrituras, 2006.

BENJAMIN, Walter. A tarefa do tradutor (1923). In: CASTELLO BRANCO, Lúcia (org). A tarefa do tradutor em Walter Benjamin: quarto traduções para o português. Traduções de Fernando Camacho; Karlheinz Barck e outros; Susana Kampff Lages; João Barrento. Belo Horizonte: Cadernos Viva Voz - Fale: UFMG, 2008. 
BORGES, Jorge Luis. Música da palavra e tradução. In: _. . Esse ofício do verso. Tradução de José Marcos Macedo. São Paulo: Companhia das letras, 2000.

BLANCHOT, Maurice. A besta de lascaux. In:_. Uma voz vinda de outro lugar. Tradução de Adriana Lisboa. Rio de Janeiro: Rocco, 2011.

CAMPOS, Haroldo. O que é mais importante: a escrito ou o escrito? Teoria da tradução em Walter Benjamin. Dossiê Walter Benjamin. Revista USP, São Paulo, n.15, p. 76-84. set./out./nov. 1992.

CASTELLO BRANCO. Lúcia. Os absolutamente sós. Belo Horizonte: Autêntica, 2000.

. Nuvens de pensamento branco: Maria Gabriela Llansol e a flor do libidinal. In: CASTELLO BRANCO, Lúcia; BAETA, Vania (orgs). Livro de Asas para Maria Gabriela Llansol. Belo Horizonte: Editora UFMG, 2007.

DERRIDA, Jacques. Torre de Babel. Tradução de Júnia Barreto. Belo Horizonte: ed. UFMG, 2002.

Che cos'è La poesia?. Tradução de Osvaldo Manuel Silvestre. Coimbra: Angelus Novus editora, 2003.

ÉLUARD, Paul. Últimos poemas de amor (1963). Tradução de Maria Gabriela Llansol. Lisboa: Relógio D’Àgua, 2002.

HOLDERLIN, Friedrich. In lieblicher blaue. Tradução de Catarina Freire Diogo. In: HOLDERLIN, Friedrich; COSTA, Daniel. Pelo infinito. Lisboa: Vendaval, 2000 .

LACAN, Jacques. O seminário Livro 20: Mais, ainda (1972-1973). Tradução de M.D.Magno. Rio de Janeiro: Jorge Zahar, 1985.

O seminário sobre a carta roubada. Tradução de Vera Ribeiro. In:

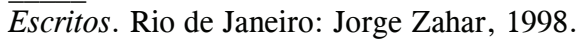


. Lituraterra. Che vuoi?. Tradução do grupo Che Vuoi?. Porto Alegre, v.1, n.1. p. 17-23, 1986.

LAGES, Susana Kampff. Walter Benjamin: tradução e melancolia. São Paulo: Editora da Universidade de São Paulo, 2007.

LISIEUX, Thérèse Martin de. O alto vôo da cotovia. Tradução de Maria Gabriela Llansol. Lisboa: Relógio d’Água, 1999.

LLANSOL, Maria Gabriela. Um falcão no punho. Lisboa: Relógio d'água, 1985. . Ardente texto Joshua. Lisboa: Relógio d'água, 1998.

. O jogo da liberdade da alma. Lisboa: Relógio d'água, 2003. $\varlimsup$ iim, 1994.

Lisboaleipzig 1 - O encontro inesperado do diverso. Lisboa: Edições Ro. Contos do mal errante. Lisboa: Assírio \& Alvin, 2004.

- Acompanhando verlaine. In: VERLAINE, Paul. Sageza. Tradução e

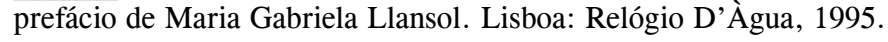

. Um jardim entre oliveiras. In: LISIEUX, Thérèse Martin de. $O$ alto voo da cotovia. Tradução e prefácio de Maria Gabriela Llansol. Lisboa: Relógio d'Água, 1999.

. Introdução: um fragmento do Diário de M.G.Llansol. In: RIMBAUD, Arthur. O rapaz raro. Tradução e prefácio de Maria Gabriela Llansol. Lisboa: Relógio D’Àgua, 1998.

. O curso natural. In: ÉLUARD, Paul. Últimos poemas de Amor. Tradução e prefácio de Maria Gabriela Llansol. Lisboa: Relógio D’Àgua, 2002. 
MANDIL, Ram. Os efeitos da letra: Lacan leitor de Joyce. Rio de Janeiro: Contra capa, 2003.

NANCY, Jean-Luc. Resistência da poesia. Tradução de Bruno Duarte. Lisboa: Edições Vendaval, 2005.

PAZ, Octavio. Tradução, literatura e literalidade. Tradução de Doralice Alves de Queiroz. Belo Horizonte: Caderno Viva voz, Fale/UFMG, 2006.

ROCHA, João Alves. O poema que estrada com o sol: a tradução para além da melancolia. Fólio - Revista de letras. Vitória da conquista, v.3, n.2, p. 111-127. $\mathrm{jul} / \mathrm{dez} 2011$.

Recebido em 07/05/2012

Aceito em 10/09/2012 